\title{
THE POLITICS OF OPERA UNDER LOUIS XIV: \\ DISSIDENT DESCENDANTS IN THE THIRD REIGN \\ Julia Prest
}

Opera crafted in a self-consciously national 'French' style came into being in the second reign of Louis XIV. The first example of a 'French' opera is generally understood to be the pastorale, Pomone, with a libretto by Pierre Perrin, music by Robert Cambert and first performed in Paris in 1671. The title page of the published edition of Pomone offers some important insights into the origins and purpose of this new genre: we read of the work having been performed at the newly created 'Academy of musical operas in the French language, established by the king on a par with those [academies] found in Italy'. ${ }^{1}$ As obvious as this may sound today, it was important in 1671 to insist on the fact that French opera had to be in the French language, particularly when it was simultaneously acknowledged that the operatic model was Italian. French opera, then, had both to be like Italian opera and, more importantly, distinct from it.

One of the principal defining features of French opera, known originally as tragédie en musique and then as tragédie lyrique, lay precisely in its deliberate rejection not only of the Italian language but especially of the Italian musical style, including its stark separation of recitative and aria. There is a delicious irony, then, in the fact that the genre's chief architect was Jean-Baptiste Lully (1632-87), the artist formerly known as Giovanni Battista Lulli. For it was Lully, who became a naturalized Frenchman the same year that Louis XIV began his personal rule, who made the genre his own and, more importantly, France's own. Indeed, the Lullian model was the point of reference for French opera for over a century, and Lully's 
works remained popular into the 1770s, although they were adapted over time to suit evolving tastes. ${ }^{2}$ Few would dispute the fact that his extraordinary influence came about and was subsequently maintained by means of the political and social structures that had been put in place by Louis XIV. Louis's heightened sense of his own kingly legacy was matched by Lully's burning ambition, and the two men shared a common belief in the power of the arts to move and influence an audience. Which brings us to the second principal defining feature of French opera: its political imperative.

French opera's political roots were written into its organizational structure, for its official home was the Académie d'opéra, established by Colbert in 1669 and renamed the Académie Royale de Musique when the royal privilege was passed from Perrin to Lully in 1672 . The only one of the royal academies concerned primarily with performance, the opera was something of a hybrid institution, both royal and public, destined to give performances both at court and in town. Lully's 1672 privilege put strict limits on the number of musicians and singers that could be used by others in their musical productions (including at that time Molière in his comédies-ballets), and although these strictures were at times contested and/or ignored, Lully's tight grasp on French music theatre was fundamentally secure. From Lully’s first tragédie en musique in 1673 until his death in 1687 the repertoire of the Académie Royale de Musique, which was housed at the Palais-Royal, consisted entirely of his works. The king and the Petite Académie, of which Lully's principal librettist, Philippe Quinault (1635-88), was a member from 1674, kept a close eye on the operas produced, the majority of which were premiered at court, usually at carnival time, and then transferred to the Palais-Royal in Paris around Easter. The fact that opera was set up both as a courtly and a public genre suggests that its message was intended to reach 
both audiences, but we should allow for the possibility that its reception may not have been identical in both locations.

Certainly it was understood that the king was glorified by the creation and existence of a new French genre intended to rival or, better still, surpass its Italian counterparts and, more specifically, by the operatic prologue - a feature of French opera that was formalized by Lully that will be discussed in more detail below. The political thrust of the operatic prologue and of the genre more broadly also accounts for its ultimate rejection of the comic form and even of comic interludes, ${ }^{3}$ for the testing task of praising France's king was particularly precarious when the audience was expecting to laugh at and thereby to question what they saw on stage. ${ }^{4}$

The creation of French opera and an operatic legacy in the second reign of Louis XIV owes much to the personal ambition of Lully and his usefulness to the king's broader project. However, Lully’s last tragédie en musique, Armide (1686) marked the beginning of the third reign in operatic terms and the difficulties inherent in a politicized form of opera were already apparent by this time. With this in mind, the question that then remains is what happened to French opera in the third reign when Lully was first out of favour and then dead, and when the ageing Louis was becoming increasingly disinterested in the genre? This last question will be addressed not by offering a survey of operas produced in France between 1686 and 1715 (which would prove little more than what is already known about Lully's towering influence and a lack of clear successors), but rather by exploring briefly a series of examples selected for what they reveal about the politics of opera during the third reign. ${ }^{5}$ The 'descendants', many of them biological descendants, of both Lully and Louis will be seen to have been 'dissident' in the sense that, to a greater or lesser extent, they challenged the status quo as it had been established earlier in the reign. Given the 
importance placed by the Bourbon monarchy upon the arts, this constitutes a significant element in our understanding of the changing nature of the regime.

\section{Prologues and Politics}

In terms of the works themselves, the most overtly political part of a French opera was without doubt its prologue. The tendency among modern critics has been to dismiss the prologue either as being extraneous to the body of the opera or as yet another example of empty - and therefore uninteresting - praise of the king. Yet this reluctance to engage more fully with the prologue may stem more from its intricacy than from its alleged simplicity. ${ }^{6}$ Christophe Deshoulières is surely right to observe that for a modern audience the prologue is 'the most difficult part to understand' ${ }^{7}$ But in our attempts to bridge that gap, we should allow for the possibility that even when the maximum number of cultural references have been deciphered and the original performance context uncovered to the fullest extent possible, the prologue might remain somewhat opaque in its function, not only because of the limits of our historical understanding but also because it was never absolutely clear and transparent in the first place.

The prologue raises a number of key questions for the modern scholar, some of which may also have troubled opera-goers and image-makers during the reign of Louis XIV. At a very fundamental level, we must ask ourselves what the prologue is and how it relates to the rest of the opera. If we accept that it is in some way a form of what we now call propaganda, we must ask ourselves if and how it differs from other better-known and perhaps better-understood forms of propaganda. With regard to the dissident descendants of the Lullian model, it will be seen that their dissident qualities are sometimes detectable precisely in their operatic prologues, although in other 
instances these have more to do with musical style and genre. Often they involve both.

The performance of an opera began with the orchestral overture à la française (another musical form formalized by Lully), followed by the prologue and then a repeat of the overture. This was then followed by the five acts of the body of the opera - a structure that echoed the five-act form of classical French tragic drama as expounded by Corneille and Racine, but with the important addition of a significant amount of dance. The inclusion of a prologue, then, was one of the key differences between spoken tragic drama and sung tragic drama at the time. ${ }^{8}$ In the majority of cases, the prologue features allegorical and mythological characters that do not reappear later in the opera, a fact that has contributed to the view that it has little or nothing to do with the rest of the work. Set in a place resembling contemporary France, the characters of the prologue speak of some kind of hero who might or might not be identified explicitly as a king; likewise, they often allude to contemporary events in terms that are not explicit but which would have been perfectly intelligible to a reasonably informed audience. ${ }^{9}$ The hero is gently reproached for being away at war or praised for having brought about peace; ultimately, he is praised by a collective celebration involving all present.

But to what end? Geoffrey Burgess suggests that the prologue functions partly as a performed dedication to its royal patron and ideal(ized) spectator. ${ }^{10}$ However, even this is not straightforward when one considers that the written dedications to Louis XIV in the published versions of Lully's scores sometimes differ markedly in both form and content - something that will be explored briefly below in the case of Armide. Likewise, critics approaching the question from a more theatrical perspective have rightly commented on the role played by the prologue in taking the audience 
members away from their daily reality and easing them into another world that not only includes le merveilleux (elements of the supernatural that were mostly absent from spoken tragedy) but was also sung throughout (the novelty of this should not be overlooked). In this context, the mixture of familiar references with allegorical or mythological beings might indeed have offered a welcome via media between the audience's daily reality and the fiction of the opera. In that sense it serves as both a transition from one world to another and as a preparation for what is to come. There may also be an additional structural purpose to the prologue, for the collective celebration of the anonymous hero of the prologue is often echoed by the collective celebration of the opera's hero at the end of the work.

Structurally, then, it is possible to account for the prologue as a performed dedication and/or as a performed transition from one world to another. But how does it work as a performance in honour of the king (a function suggested both by the dedicatory argument and by our understanding of the references to a local hero)? And how does the subsequent portrayal of the opera's principal hero support or detract from this? The widely-held understanding that the invisible hero of Lully's opera prologues is or, rather, represents Louis XIV seems irrefutable in the context of 1670s and 1680s France. Couvreur's suggestion that the prologues kept Louis XIV on the stage when he had given up dancing in court ballets is an interesting one that hints at some important questions about the best way for the king to promote his image in public and specifically through theatre. ${ }^{11}$ Although the blanket view that the prologues constitute straightforward propaganda is an oversimplification, it is certainly true that some of the tributes made to the hero of Lully's prologues are relatively straightforward. This is particularly the case when the hero is praised for having brought peace to France and when this reflected an on-going historical reality. 
But, for there to be a new and welcome peace, there must of course have been war first. Lully's first four operas were composed during the Dutch wars: Cadmus et Hermione (1673), Alceste (1674), Thésée (1675) and Atys (1676). The tension between the attractions of pleasure and the trials of war is not overlooked and is generally addressed via a dialogic structure between glory and war on the one hand and peace and the arts on the other. At the end of the dialogue, a rhetorical space is created that allows the ensuing opera to proceed. It should be noted that the dialogues do sometimes include references to the horrors of war in which at least one critic reads an 'undeniable element of criticism'. ${ }^{12}$ The Treaty of Nijmegen in 1678 liberated opera from this awkward tension and peace is openly celebrated in the unremittingly joyful prologue to Bellerophon (1679), ${ }^{13}$ featuring Apollo praising the greatest king on Earth, and in that of Proserpine (1680), which, with a return to the dialogic structure, stages the glorious triumph of Peace over Discord.

\section{The Third Reign Begins: Armide (1686)}

Lully's Armide (first performed in February 1686) is widely considered to be his finest opera, and La Gorce's view that it represents the apogee of Lully's tragédie en musique as the representative genre of French opera is widely shared. ${ }^{14}$ Its chivalric subject was chosen by the king, and its prologue is closely aligned with more official forms of kingly encomium. In addition to the customary references to a masterful hero and, in this instance, to peace, the prologue to Armide features a transparent and deliberate reference to a very precise and very recent political event: the Revocation of the Edict of Nantes in October 1685. The allegorical figure of Wisdom sings:

In the midst of the repose that he guarantees to humankind 
He brings down with his powerful hands

A monster that has long been considered invincible. ${ }^{15}$

The key term here is 'monster' (monstre), commonly used in the Mercure galant newspaper and elsewhere to designate what was perceived as the heresy of Protestantism. In both the newspaper and the operatic prologue the heroic Louis XIV is thus depicted as having slain the monster of heresy. ${ }^{16}$ The prologue is, in modern parlance, absolutely on message. Why, then, did Armide not receive a court premiere and why am I arguing that it epitomizes the precarious nature of the political dimension to French opera and the beginning of the third reign?

To a certain extent, the reasons are circumstantial. The ill-health of the composer and then of the king led to delays, which in turn necessitated a town premiere (the anticipated performance of Armide at the court's carnival celebration having been replaced by the Ballet de la jeunesse by Lalande). The fact that Louis the Grand Dauphin - but not Louis the king - attended several public performances of the work is also significant. Certainly, we know that Lully was disappointed by this turn of events as he wrote openly about it in his dédicace to the published version of the score in 1686 . Here Lully juxtaposes the undeniable public success of his new work with the fact that it has not been seen by the king, the patron and theoretical spectator of French opera par excellence. In words that appear to combine rhetoric and brute honesty, Lully admits that he seeks only the king's approbation, hinting at the political usefulness of the genre that he has forged: 'the acclaim of the whole of Paris is not enough for me; I only wish to dedicate all the efforts of my genius to you, Sire'. ${ }^{17}$ In anticipation of a belated invitation to perform the work at court, Lully dedicates the print version to his king. 
In the end, the court premiere of Armide did not take place until after Lully's untimely death in March 1687, and then, it seems, only at the behest of the Dauphin. Something had clearly gone awry. We should not overlook the significance of the scandal of Lully's sexual relationship with the page, Brunet, which had erupted in 1685 and caused considerable displeasure to Louis XIV. But this is only a partial explanation. At the same time that Lully was taking his model of French opera to its exemplary heights, the genre's usefulness was increasingly questionable as the heroism celebrated in the prologue became increasingly divorced from the reality of France's king. Furthermore, if the operatic prologues featured heroes who could still be identified with the official image of Louis XIV (if not with his reality), the operas themselves had a tendency to feature more dubious heroes. The hero of Armide, Renaud, is a case in point, for he is a weak man who spends much of the opera powerless under Armide's spell. ${ }^{18}$ In the 1718 edition of the score, the decorative headpiece to Act II features a hero who looks more vaincu (vanquished) than, as the text below would have it, invincible (invincible) (see Figure 10.1) [INSERT

FIGURE 10.1 HERE OR SOON AFTER]. It was widely known at least to the court audience that Louis XIV had throughout the 1660s and 1670s conducted a number of extramarital affairs, some more scandalous than others, and that his relationship with the more pious Madame de Maintenon was, as far as we know, only formalized in secret in 1683 following the death of Queen Marie-Thérèse earlier that year. While tragédie en musique, with its mythological and chivalric subject matter, was hardly a genre to pass any moral judgement on sexual infidelity, its political dimension did invite audiences to consider the possibility of the political risk to a monarch of falling under the influence of a woman - a possibility that Louis XIV himself acknowledged in his Mémoires in a passage that was later suppressed. ${ }^{19}$ Georgia Cowart has 
suggested that Lully's later operas featuring an héroisme manqué used their flawed protagonists 'as a negative reinforcement of the perfection of Louis XIV as the "greatest hero", ${ }^{20}$ This is a viable interpretation, but alongside it sits the equally viable possibility that some audience members might have been reminded of the parallels between the flawed operatic hero and their flawed king. ${ }^{21}$

If we cannot arrive at any definitive answers to these questions, what is clear is that there were a series of tensions at play in all these operas, between the fiction of the prologue and that of the opera, between the operatic fiction and the increasingly fictional construction of the heroic Louis XIV, and between the fictional Louis XIV and the reality of the later (and perhaps also earlier) portions of his reign. If the collective emphasis in opera is on military heroism, the king's dwindling heroism in this regard seems particularly poignant and open to comment.

Armide is often hailed as Lully's last opera, but this is not strictly the case: rather, it was Lully's last tragédie en musique. In the course of his life, Lully had established a solid track record of sensing which way the politico-musical wind was blowing, having already embraced and then abandoned comédie-ballet in favour of musical works that were sung in French throughout. And so, at the same time that he hedged his bets by trying to convince Louis XIV to restore his favour to the tragédie en musique, Lully embarked on another trajectory in the form of his three-act heroic pastorale, Acis et Galatée. The librettist for this work was Jean Galbert de Campistron, who was employed by the duc de Vendôme. ${ }^{22}$ The duc, who had a reputation as something of a libertine, and his brother, Philippe, commissioned Acis et Galatée as part of a week-long fête held at the duc's chateau in Anet in honour of the Dauphin in September 1686. The work features a prologue that offers a number of insights into the politico-musical climate of the time. Set in the chateau at Anet, 
thereby minimizing the distinction between fact and fiction, the prologue opens with Diana anticipating the arrival of the Dauphin, who is described as 'the son of the most powerful and most just of kings'. ${ }^{23}$ While the Dauphin is seen in relation to Louis $\mathrm{XIV}$, it is nonetheless significant that a new living individual had made his way into the political prologue and particularly one to which the name of Lully is attached. To a degree, then, Lully had thus become a dissident descendant of his own tradition. And, although his musical style remains unmistakeably 'French', the pastorale makes little attempt to engage with the heroic themes of the tragédie en musique.

The question arises too of the degree to which the Dauphin, as the new idealized spectator of French opera, represents the dissident descendant of his father in matters of high culture. The appearance in the prologue of Apollo on a suspended cloud draws attention to the king's absence at the same time that it seeks to atone for it: Apollo sings of the king's love for his worthy son, thereby legitimizing the prologue's new object of praise, and then expresses the following wish: 'May these same songs on a more auspicious day entertain the king himself again'. More than mere politesse or even wishful thinking, this is a revealing and poignant reminder that Louis XIV remains in theory but no longer in practice the privileged spectator of French opera. There is reason to believe that Louis XIV was displeased by this fête, ${ }^{24}$ and we know that the opera was never performed for the king, but that it was transferred to the Académie Royale de Musique the same year. The significance of an operatic prologue praising someone other than - albeit in addition to - Louis XIV reaching not just the court nobility at Anet but also the wider opera-going public in Paris should not be underestimated.

Lully's death a few months later following a conducting injury, is one of the most notorious in musical history: he contracted gangrene having stabbed himself in 
the foot while conducting a performance of his Te Deum marking the king's recovery from an operation on his anal fistula. Despite having fallen from favour, Lully's operatic legacy was, however, sufficiently well-established to make its mark on the third reign and beyond. Indeed, the great paradox of French opera in the decades immediately following Lully's death is the fact that it featured a large number of premieres of new operas alongside a large number of revivals of Lully's. ${ }^{25}$ As Lully's work lived on, other composers were finally able to have their works performed at the Académie Royale de Musique. Some tried their hand at the tragédie en musique, while others experimented with different operatic forms, often with a comic and/or Italian bent. What is commonly overlooked is the possibility that Lully himself had been moving in a new operatic direction and that he himself might have undermined his own legacy had he lived long enough to do so. Instead, the task fell into other hands. $^{26}$

\section{Dissident Descendants}

It soon became clear that Lully's sons, Louis and Jean-Louis, were unable to fill their father's operatic shoes. Their opera, Zéphire et Flore, a collaborative work probably involving other composers as well, was produced in 1688 on the anniversary of Lully's death. Its published score is dedicated to Louis XIV and features a warm appeal to their father's royal patron (and Louis Lully's godfather). The opera includes a prologue that is reminiscent of the Lullian model, although one critic has deemed the work 'a reversal of ... the absolutist image of the Sun', declaring that the central character of Boreas is an 'absolutist villain'. ${ }^{27}$ Although this is a knowingly provocative reading (it seems unthinkable that Lully's heirs would have sought to goad the king), it does highlight the unworkability of the hereditary model for control 
of the opera, and the difficulties inherent in finding a successful form of kingly praise, particularly in a genre in which the king had lost interest. The work did not receive any sign of kingly approval and enjoyed only a short performance run in town.

One response to the king's waning interest in opera was, as we have seen, to praise his descendants who were more interested in the genre, notably the Dauphin. Like Lully's Acis et Galatée, André Campra's Le Carnaval de Venise (1699) featured a prologue that praised the Dauphin alongside Louis XIV. ${ }^{28}$ The goddess Minerva comments on the importance of attracting the attention of 'a great prince whom I love', which could conceivably have been Louis XIV were it not for the fact that a few lines later she urges all those around her to 'serve the son of the world's greatest king' - a refrain that is then taken up by the chorus of the divinities. ${ }^{29}$ Only later in the prologue does Minerva urge the assembled company to 'celebrate a most glorious king'. The king is praised in conventional terms for having brought peace to France, but the use of the term 'mémoire' (memory) is significant: of the glorious king, Minerva sings 'a thousand magnificent exploits sanctify his memory' ${ }^{30}$ It would seem that the work is in practice dedicated to the Dauphin, a regular attendee at the Académie Royale rather than to the king. Or rather, that it is a forward-looking work for whom the significance of Louis XIV - increasingly interested in sacred music - is now only a memory.

Le Carnaval de Venise is significant for other reasons too, notably for its departure from the Lullian operatic model and the challenges it thus posed to the French style. Campra's opera is a three-act opéra-ballet rather than a five-act tragédie en тиsique; it features not mythological or chivalric heroes, but bourgeois characters from contemporary Venice - an element that aligns it more closely with spoken comedy and specifically with the commedia dell'arte. Given that the Italians were 
notorious for their privileging of satire and parody and that the resident troupe of Italian actors had only two years earlier been exiled from France by order of the king, this is not insignificant. Indeed, the librettist for Le Carnaval de Venise was none other than Jean-François Regnard, who had written a number of works for the Italian troupe and who was also known to be associated with the libertine nobility.

The fact that the characters of the opera attend a performance of Orfeo dell'inferi is perhaps a reminder of the first Italian opera that had been performed for the French court during Mazarin's unsuccessful attempts to bring the genre to his adopted country, Rossi's Orfeo (performed in Paris in 1647), not least because it is written entirely in Italian. The interpolated opera also alludes to the scene in Louis Lully’s Orphée (1690) in which Orpheus is pitted against Pluto. ${ }^{31}$ According to Cowart, where Louis Lully's opera ends in the tragic mode, Regnard's text and Campra's music turn Pluto into 'a ridiculous buffoon' ${ }^{32}$ Le Carnaval de Venise thus departs from the Lullian model in a number of key ways: in its use of the Italian language in Orfeo dell'inferi, its comic leanings (and possible use of satire), its metatheatrical dimension and its use of Italianate music, particularly in its divertissements featuring da capo arias. ${ }^{33}$ From the perspective of the hallowed tragédie en musique tradition, all these elements made Campra a dissident descendant of French opera, just as the Dauphin's enjoyment and promotion of such works arguably made him a dissident descendant of Louis XIV, at least in operatic terms. Together, Campra and the Dauphin offered what has been described as no less than 'a new form of theater' in an 'operatic countercourt'. ${ }^{34}$ Although in operatic terms Campra, who was of mixed Italian and French heritage, is the most viable candidate for the French opera composer who best bridged the great gap between Lully and 
Rameau (whose first opera was not performed until 1733), it is in this context unsurprising that he never found favour with the ageing king.

The emergence of the Italian style on the French operatic stage in the third reign of Louis XIV ignited a debate that would rage throughout most of the eighteenth century about the respective merits of French and Italian dramatic music - one that Lully (and no doubt Louis XIV) had hoped to avert by establishing an irrefutable model for posterity. In 1702, the abbé François Raguenet published his comparison of French and Italian opera, complete with a full reprint of the royal privilege granted to Moreau for printing the work. This should not, then, be considered a subversive book as such; rather, the challenge it poses to the desired status quo of French supremacy in matters operatic is more subtle and perhaps more effective as a result. For Raguenet purports to be objective, his stated aim is to offer 'a fair comparison' and 'an accurate evaluation' of the respective merits of both operatic traditions. ${ }^{35}$ Certainly, Raguenet speaks with considerable authority being both a connoisseur of opera and having heard performances in both France and Italy, and his tone is mostly measured and even. Raguenet, who identifies as a Frenchman throughout the volume (he writes repeatedly of French works as 'our operas') acknowledges the merits of the LullyQuinault model, remarking that 'few tragic or comic works are more beautiful than the majority of Quinault's operas'; ${ }^{36}$ he praises, among other things, the range of voice types found in French opera, the French divertissements, the skill of France's dancers as well as the finesse and delicacy of the French orchestra's performance style and the tasteful costumes employed. He singles out the particular contributions of Lully to French operatic music and of Beauchamps (Louis XIV's former dance instructor) to its dance, opining that in these respects the French model is indeed superior to the Italian one. 
By far the greater part of Raguenet's volume is, however, dedicated to the ways in which Italian opera is, in his view, superior to its French counterpart. He begins with the familiar point about the Italian language, and particularly its vowels, being more suited to being sung (a point with which most opera singers today would concur); Italian arias, he claims, are more varied in style, as well as more chromatic, harmonically inventive and expressive and therefore more engaging than their French counterparts, which can sound repetitive and insipid. Raguenet picks out Lully as unsurpassed in France but then insists, rather perversely, that Lully was Italian and that his lone example merely serves to support the view that Italian opera is superior to the French variety - an argument, we can be sure, that would have enraged the naturalized Frenchman had he still been alive to hear it. Raguenet goes on to describe Lully and his influence as 'phoenix-like' and insists on his apparent irreplaceability: 'nothing beautiful has been composed in France since Lully's death', ${ }^{37}$ recommending instead that music-lovers travel to Italy to seek operatic satisfaction. Many other elements of Italian opera are commended, but perhaps the most controversial element of Raguenet's appreciation of Italian opera lies in his praise for the castrato singer who, he maintains, is better than any other, male or female, found on the French stage. Raguenet's particular appreciation of the castrato performing the role of operatic lover, born of his experiences hearing Italian opera in Rome, was wholly antithetical to the standard audience in France. There was simply no place for the castrato in an operatic tradition that was set up as being distinctive from the Italian variety that it sought to rival. ${ }^{38}$

Raguenet's controversial treatise was met with a spirited riposte. ${ }^{39}$ Written in the form of three fictitious dialogues and a letter, Le Cerf's pamphlet takes Raguenet's arguments apart one by one and reasserts the primacy of French opera. 
This in turn prompted Raguenet to write his Défense du Paralèle des Italiens et des François, en ce qui regarde la musique et les opéra, published in Paris by Barbin a year later. Although some time is spent debating whether or not it matters that Lully (or Lulli) was Italian born and the respective skills of Italian and French musicians, the substance of the debate between the two men is aesthetic. French opera is defended on the grounds of good taste, simplicity and naturalness in contrast with the excesses of Italian opera (or, viewed from the opposing side, Italian opera is praised on the grounds of diversity and interest, in contrast with the uniformity and monotony of French opera). As Le Cerf had put it, 'on the one hand naturalness and simplicity, on the other affectation and excess; here, authenticity embellished with good judgment; there, falseness masked by a thousand refinements and laden with the excesses of a monstrous science'. ${ }^{40}$ He likens the opposition to the recent Quarrel of the Ancients and Moderns, although this musical quarrel was to acquire a name of its own later in the eighteenth century: the 'Querelle des bouffons' of the 1750s.

The matter of royal involvement is not, however, entirely absent from the discussion. On the question of Italian-style opera appearing in France, Raguenet writes revealingly in his Défense du Paralèle about one of the most prominent supporters in France of Italian music, referring to 'one of our princes who, out of respect, will remain anonymous' and about whom he comments 'he is one of the most knowledgeable people around; nobody respects the fine arts more than he does and his open appreciation of Italian music is an argument in favour of this type of music'. ${ }^{41}$ The mystery prince may be the Dauphin, or, perhaps, given the emphasis on his knowledge and appreciation of the fine arts, the future regent, Philippe II, duc d'Orléans. Either way, the fact that Raguenet can legitimately harness the support of a close relative of the king to bolster his own pro-Italian viewpoint is particularly 
rhetorically effective because it draws on the supposed links between French opera and the French monarchy. If Le Cerf can accuse him of poor taste, it is more difficult to accuse Raguenet ergo of betraying France when at least one prominent member of the French royal family shares his penchant for the Italian style.

This, perhaps, is the crux of the matter. The pleasure-seeking Dauphin was, until his death in 1711, evidently more in tune than his ailing father with French operatic tastes in the third reign, and the king's neglect of the genre was compounded by his son's interest in it. Louis XIV's longevity allowed the Lullian operatic model to endure, mostly in the form of revivals that were increasingly remote from their original performance context, but also with some new tragédies en musique, just as his son's personal tastes allowed new 'French' forms to develop as well. Somewhat surprisingly, perhaps, the tradition of including some kind of prologue in the tragédie en musique persisted right up until Rameau's Zoroastre (1749), although its efficacy as a form of encomium in the third reign became increasingly questionable and prologues frequently focussed on other matters such as aesthetics. Saint-Simon records how in 1712 the abbé Servien attended the performance of an opera whose prologue featured 'an excessively laudatory refrain in praise of the king that was repeated several times over'; the abbé apparently inverted the kingly praise 'and began to sing loudly in a most ridiculous fashion' ${ }^{42}$ His intervention was, we are told, met with laughter and applause from the audience members before the abbé was briefly exiled from Paris. When he parodied the kingly praise in the prologue to another opera in 1714, Servien's quip was taken up and applauded by the audience in the parterre, but on this occasion he was sent to prison in Vincennes. ${ }^{43}$ Even allowing for the fact that Saint-Simon was famously opposed to Louis XIV, his account reminds us of at least two key points: firstly, that it was increasingly difficult in the 
third reign to control audience response - the monarchy was already losing its grip over the public sphere in Paris - and secondly, that opera was still in some fundamental way political.

If the tragédie en musique outlived its usefulness to the king in the third reign, it is also the case that the king outlived his direct usefulness to the genre of French opera, which continued to explore new paths more or less independently of him. ${ }^{44}$ Louis XIV of course also outlived his son, the Grand Dauphin, and his grandson, the duc de Bourgogne, who died in 1712. It is surely revealing that one of the first acts of Philippe d'Orléans when he took over as regent in 1715 was to summon a troupe of Italian actors to France. The troupe, led by Luigi Riccoboni made its French debut in May 1716. Meanwhile, having been snubbed by Louis XIV, the Italianate Campra now found himself much closer to royal power by virtue of his association with Philippe d'Orléans who finally made him sous-maître at the Chapelle Royale in 1722. We began this chapter with one of the great ironies of operatic history, namely that French opera was founded by Italian-born Lully. Let us close with another: that French opera as an institution founded under Louis XIV survived the French Revolution more than a century later owing both to its hybrid status as a royal and public genre and to the undeniable position it occupied as a beacon of French culture. ${ }^{45}$ This in turn sheds light back on the paradox of how opera fared during the third reign, when the Lullian model was simultaneously contested and consolidated. Its vexed status in fact allowed the tragédie en musique to shift from being a contemporary political genre, with all the precariousness that this entailed, into a more comfortably classic one whose place in posterity was now secure. 
${ }^{1}$ Pomone opera, ou representation en musique (Paris, 1671). This phrasing echoes that of the Letters Patent drawn up in 1669 when the Académie was first established. All English translations in this chapter are my own.

${ }^{2}$ See, among others, L. Roscow, 'How eighteenth-century Parisians heard Lully's operas: the Case of Armide's fourth Act', in J.H. Heyer (ed.), Jean-Baptiste Lully and the Music of the French Baroque: Essays in Honor of James R. Anthony (Cambridge, 1989), pp. 213-38.

${ }^{3}$ While some of Lully's early operas featured the occasional comic scene or character, including the cross-cast nurse in Cadmus et Hermione (1673) and the cheerful Charon in Alceste (1674), these elements disappeared from subsequent operas.

${ }^{4}$ See J. Prest, 'The Problem of Praise and the First Prologue to Le Malade imaginaire', Seventeenth Century French Studies 23 (2001), pp. 131-41.

${ }^{5}$ The third reign appears to have witnessed both the first performance of a French opera with a libretto written by a female author and the first performance of a French opera by a female composer. These are, respectively, Henri Desmarets' Didon (libretto by Louise-Geneviève de Saintonge) in 1693 and the tragédie en musique, Céphale et Procris by Elisabeth Jaquet de La Guerre in 1694.

${ }^{6} \mathrm{~A}$ handful of individuals have recently given the prologue welcome attention. These include F. Escal, 'Fonctions et évolution du prologue d'opéra', in Le Livret malgré lui: actes du colloque du Groupe de recherche sur les rapports musique-texte (GRMT) (Paris, 1992), pp. 31-44; G. Burgess, 'Revisiting Atys: Reflections on Les Arts Florissants' production', Early Music 34 (2006), pp. 465-78 ; and R. Harris-Warrick, 'Le Prologue de Lully à Rameau', in S. Serre and M. Noiray (eds), Le Répertoire de l'Opéra de Paris (1671-2009): analyse et interprétation (Paris, 2011), pp. 199-212.

${ }^{7}$ L'Opéra baroque et la scène moderne (Paris, 2000), p. 348.

${ }^{8}$ Another key difference was the fact that Lully's operas ended happily - something that may not be unrelated to the thrust of the prologue and the invitation to the audience to think about contemporary events alongside historical and mythological ones.

${ }^{9}$ For more on these allusions, see A. Niderst, 'L'Actualité politique dans l'opéra français à la fin du règne de Louis XIV 1686-1715', in Regards sur l'opéra: du Ballet comique de la Reine à l'opéra de Pékin (Paris, 1976), pp. 187-212.

10 'Revisiting Atys', p. 466. Deshoulières, following Escal, has also likened the prologue to a literary envoi or dédicace in a published book: see L'Opéra baroque, p. 346. 
${ }^{11}$ M. Couvreur, Jean-Baptiste Lully: musique et dramaturgie au service du prince (Paris, 1992), p. 325. On the specific dangers of Louis XIV exposing his mortal body when performing in court ballets, see J. Prest, ‘Conflicting Signals: Images of Louis XIV in Benserade's Ballets', in S. Alyn Stacey and V. Desnain (eds), Culture and Conflict in Seventeenth-Century France and Ireland (Dublin, 2004), pp. $227-41$.

${ }^{12}$ B. Norman, Touched by the Graces: the Libretti of Philippe Quinault in the Context of French Classicism (Birmingham, AL, 2001), p. 53.

${ }^{13}$ The libretto for Bellerophon was not by Quinault, who was in disgrace (see fn19), but by Thomas Corneille and Fontenelle.

${ }^{14}$ J. de La Gorce, Jean-Baptiste Lully (Paris, 2002), p. 685.

15 'Au milieu du repos qu'il assure aux humains, /Il fait tomber sous ses puissantes mains / Un monstre qu'on a cru si longtemps invincible.' Philippe Quinault, Livrets d'opéra, ed. by Buford Norman (Toulouse, 1999), vol. 2, p. 252.

${ }^{16}$ See, among other examples, Le Mercure galant (February 1686), part II, p. 99.

${ }^{17}$ Jean-Baptiste Lully, Armide, tragédie (Paris, 1686), [n.p.].

${ }^{18}$ For a thoughtful and thought-provoking reading of Armide, see T. Downing, 'Opera, Dispossession, and the Sublime: the Case of Armide', Theatre Journal 49 (1997), pp. 168-88.

${ }^{19}$ Moreover, Lully and Quinault's opera, Isis, had provoked a scandal in 1677 when it was interpreted by some as an allegory for the king's love affairs, depicting Madame de Montespan as the jealous Juno. As a result, Quinault spent two years in disgrace and Lully was obliged to work with other librettists. ${ }^{20}$ The Triumph of Pleasure: Louis XIV and the Politics of Spectacle (Chicago, 2008), p. 134.

${ }^{21}$ Some audience members may even have recalled that in 1664 the adulterous king had performed the role of Renaud in the Ballet des amours déguisés.

${ }^{22}$ Another Lully opera written to a libretto by Campistron, Achille et Polixène, remained incomplete on Lully's death and was finished by his student and secretary, Collasse.

${ }^{23}$ Acis et Galatée, pastoral hérö̈que en musique (Paris, 1690), [n.p.].

${ }^{24}$ See Cowart, Triumph, p. 142.

${ }^{25}$ Armide was revived five times during the third reign (in 1688, 1692, 1697, 1703, 1713-14).

${ }^{26}$ The fascinating phenomenon of the operatic parody falls beyond the scope of the present chapter, which is concerned with mainstream opera. For more information on operatic parodies during the third 
reign, see Cowart, Triumph, pp. 150-5; and C. Gordon-Seifert, 'Heroism Undone: the Erotic Manuscript Parodies of Jean-Baptiste Lully's Tragédies en Musique', in L. Austern (ed.), Music, Sensation, and Sensuality (New York, 2002), pp. 137-66.

${ }^{27}$ G. Cowart, 'Carnival in Venice or Protest in Paris? Louis XIV and the Politics of Subversion at the Paris Opera', Journal of the American Musicological Society 54 (2001), p. 275. See also Cowart, Triumph, p. 146.

${ }^{28}$ See D. Fader, 'The "Cabale du Dauphin," Campra and Italian comedy: the Courtly Politics of French Musical Patronage around 1700', Music \& Letters 86 (2005), pp. 380-413.

${ }^{29}$ Le Carnaval de Venise, ballet (Paris, 1699), [n.p.].

30 'Mille exploits éclatants consacrent sa mémoire.'

${ }^{31}$ Cowart has even suggested that it also satirizes roles taken by Louis XIV in the court ballet $L e$ Carnaval, mascarade royale (1668): see Triumph, pp. 202-07.

${ }^{32}$ Cowart, Triumph, p. 204.

${ }^{33}$ According to La Gorce (pp. 255-6), the only fully-fledged Italian opera performed in France between 1662 and 1752 was Paolo Lorenzani's Nicandro e Fileno, performed at Fontainebleau in 1681.

${ }^{34}$ Cowart, Triumph, p. 204.

${ }^{35}$ François Raguenet, Paralèle des Italiens et des François, en ce qui regarde la musique et les opéra (Paris, 1702), p. 2.

${ }^{36}$ Raguenet, Paralèle, p. 7.

37 'Il ne se fait plus rien de beau en France depuis la mort de Lully.' Raguenet, Paralèle, p. 67.

${ }^{38}$ For more information about French attitudes towards the castrato, see J. Prest, 'On Stage, in Chapel and in the Bedroom: French Responses to the Italian Castrato', Seventeenth Century French Studies 32 (2010), pp. 154-66.

${ }^{39}$ J.-L. Le Cerf de La Viéville, Comparaison de la musique italienne et de la musique française (Brussels, 1704).

${ }^{40}$ La Viéville, p. 183.

41 'Un de nos Princes que je ne nomme pas ici par respect. C'est un des plus savans que nous ayons; personne ne fait plus d'honneur que lui aux beaux Arts; \& son goût déclaré pour la Musique Italienne est un préjugé en faveur de cette Musique.' Raguenet, Défense, p. 51. 
${ }^{42}$ Saint-Simon, vol. 23, pp. 121-22.

${ }^{43}$ Saint-Simon, vol. 24, p. 154.

${ }^{44}$ A notable exception to this was the creation in 1712 of the position of inspecteur général de l'opéra, to which Louis XIV appointed the composer André Cardinal Destouches. See R. Fajon, L'Opéra à Paris du Roi Soleil à Louis le Bien-Aimé (Geneva, 1984), p. 83.

${ }^{45}$ See V. Johnson, Backstage at the Revolution: How the Royal Paris Opera Survived the End of the Old Regime (Chicago, 2008). 